\title{
Understanding the Cozy Relationship between Pakistan ISI and Lashkar-e-Taiba
}

\author{
Mustapha Kulungu \\ ILM Foundation Institute of Los Angeles, Los Angeles, USA \\ Email: drmkulungu@yahoo.com
}

How to cite this paper: Kulungu, M. (2021) Understanding the Cozy Relationship between Pakistan ISI and Lashkar-e-Taiba. Open Access Library Journal, 8: e7884. https://doi.org/10.4236/oalib.1107884

Received: August 23, 2021

Accepted: October 9, 2021

Published: October 12, 2021

Copyright (C) 2021 by author(s) and Open Access Library Inc.

This work is licensed under the Creative Commons Attribution International License (CC BY 4.0).

http://creativecommons.org/licenses/by/4.0/

http://creativecommons.org/lice

\begin{abstract}
This article evaluates to what degree the relationship between Pakistan and militant groups, primarily Lashkar-e-Taiba (LeT) operating within its border, has influenced Islamabad's counterinsurgency approach. The article succinctly describes the process that led to the formation of Pakistan and its ongoing fight with India since then over Jammu and Kashmir. It further discusses India's overall strategic recourses in the Disputed Territory that have driven it to interpose in the internal affairs of its neighbors, principally Pakistan and Afghanistan. The interventionist behavior of India in the region generates strong anti-India sentiment among Pakistanis and Afghans. And in turn, the Pakistan militant groups cunningly use this anti sentiment as red meat to feed and reinforce the mindset of their followers and Kashmir nationals. Also, it addresses the developmental impact these militant groups have on Pakistan's strategy to counter India's dominance over the Disputed Territory of Kashmir. Additionally, this research highlights that while LeT has been previously a vibrant element of Pakistan's regional stratagem, the group capability has morphed beyond Pakistan's ISI's control. It operates independently of the political development, and its organizational structure has extended beyond Jammu and Kashmir. The seeming threat poses by Indians over the Disputed Territory of Kashmir indeed creates a security quandary for the Pakistani army and security establishments. For over seven decades, India and Pakistan have clashed over the Kashmir-Occupied Territory, critical to both countries' economies and prosperity. Islamabad has used LeT as its proxy primarily to keep India entangled in the economic drain in the Kashmir area while Pakistan continues to influence Afghanistan. This study is interested in understanding past events in an attempt to interpret the facts and explain the cause of occurrences, and their impact on the present events; thus, it is historical research. Both primary and secondary sources have been consulted to conduct this inquiry. Grasping the changing regional aspects of terrorism may be significantly advantageous in policymaking and intervention strategy. The
\end{abstract}


research results highlight the significance of the entrenched geopolitical conflict and interests of the two nations and the order in comprehending terrorism. And the religious hatred of the Indian Hindus is not the principal driving force of militant groups of Pakistan attacks against India; instead, it is used as a vehicle by jihadists to make a point. The driving factor behind their attacks toward New Delhi is against its hegemonic desires of territorial control. Psychologically, the issue has been the building and making of the separate and unique identity of the people of Jammu and Kashmir. The research contributes to a clear understanding of the past and provides some possible ways forward. The study concludes that Islamabad and New Delhi need new strategies to mend their relationship and develop a plan to restore their security and stability. Lastly, it suggests some pragmatic recommendation steps India and Pakistan might take to overcome their differences and co-exist peacefully as neighbors.

\section{Subject Areas}

Military Science, Politics, Sociology

\section{Keywords}

Pakistan ISI, LeT, Terrorist Groups, Jammu and Kashmir, Cozy Relationship, Regional Conflicts, Power Broker

\section{Introduction}

\subsection{Preface}

As a student of history, we learn that the past reminds us that no bordering nations have ever lasted and developed on protracted quarrelsome relationships. Hindus, Muslims, and other minority groups lived together in India before 1947 as a British Raj. Bates (2011) postulated that creating new states has been a common recurrence throughout the world [1]. There are a plethora of examples in Africa, the Middle East, South Asia, Latin American, to name just a few. Thus, the division of the British Raj to India and Pakistan was not a unique phenomenon. In essence, history has repeated itself, as is the case of India and Pakistan. Whenever a whole unit is divided into two, it formed two separate entities, so India and Pakistan were created at the same time when the British Empire decided to leave the subcontinent.

In 1947, the British monarch divided India into two distinct colonies, giving India large territory to the majority Hindus and a smaller part, Pakistan, to predominantly Muslims. According to Akhilesh Pillalamarri (2019), many historians have told us that the division into two countries took place because of their religious differences [2]. And others have suggested that partition happened not because Hindus and Muslims could not coexist, instead because the establishments from both Hindu and Muslim communities could not come to the term 
for power-sharing. But, let the truth be told, using religious differences as the deciding factor to the partition was the greatest deceit of the twentieth century. Regrettably, after the division, both colonies never developed a positive friendship and resulted in an ongoing dispute that has lasted over seventy years.

\subsection{History of Hostile Relationship between India and Pakistan}

India and Pakistan have had a complex and hostile relationship due to several historical and political events. The two countries had thousand years of joint existence before the British Raj and eventually started to exist as two distinct nation-states in 1947. The first war welcomed the birth of these nations, which marked the beginning of endless conflicts [3]. The first war in 1947 began when armed tribespeople from Pakistan invaded Kashmir. Kashmir turned to India for military assistance to allow India to take control of its defenses, communications, and foreign affairs. The conflict ended in 1949 when the United Nations intervened and arranged for a ceasefire.

Nevertheless, the tense relationship between the two countries reemerged in 1965, following a series of clashes across the India-Pakistani border. Pakistan soldiers crossed the Line of Control into Indian administered Kashmir, causing conflicts between the two nations. The invading Pakistan soldiers attempted to start an insurgency against India. However, the war was short-lived as it ended in 1966 after officials from both countries signed a declaration that affirms their peace commitment.

Pakistan erupted into civil war in 1971; as time went on, it paved the way for the third war between India and Pakistan. First, India became involved in the conflict after the Pakistan air force launched an attack on airfields in India. India responded with a coordinated attack on Pakistan's land, sea, and air leading to the latter's surrender and eventual independence of the East [4]. Then, in 1974, India triggered a hostile relationship by testing a nuclear weapon near its border with Pakistan in the Smiling Buddha operation.

In 1989, Muslim parties in Kashmir started armed resistance against Indian rule, complaining that elections were rigged in 1987. The claims made part of the citizens demand independence while the others wanted to unite with the Pakistanis. In 1998, both countries conducted nuclear tests, with India conducting its five underground atomic tests near its border with Pakistan. The move triggered a similar response from Pakistan who detonated six nuclear devices in Shanghai Hills. These nuclear activities called for the international community's intervention who condemned the actions, and urged the two nations to cease the programs.

At the turn of the century, five armed terrorists entered and opened fire in the Indian parliament leading to the deaths of nine individuals [5]. Indian government placed the blame on Pakistan-backed Kashmir militants. The two countries responded by massive troops build-ups along the border. In 2007, 68 people, most being Pakistan citizens, died when the Samjhauta Express was bombed in Panipat, 
New Delhi. In 2008, Lashkar-e-Tayyiba associates attacked several buildings in Mumbai, killing approximately 160 people. In 2019, Jaish-e-Mohammed, a Pakistan-based terrorist group, conducted a suicide car bomb attack in Indian territory, killing more than 40 people. The Indian military responded by numerous airstrikes across the Line of Control.

\section{Research Methodology}

This study attempts to delve into the cozy relationship between Pakistan ISI and LeT, and understaning the ongoing conflict between India and Pakistan. However, Pakistan Inter-Service Intelligence continues to support this militant group. Thus, reviewing the primary sources of existing data was deemed appropriate and used to investigate what had been studied and produced by various groups. This research understands that by studying past events, perspective is everything. My primary sources of information emanated from individuals or groups of people who participated or witnessed an event and recorded it. Thus, the study consulted many materials; they include written speeches, minutes of meetings, personal letters, records, joint military reports, archival intelligence data from open source, government agencies reports, and much more. Also, for the secondary sources, it means a piece of secondhand information written by someone other than the eyewitnesses of the event. For this reason, the study consulted academic articles, theses, newspapers, such as the Times of India, the Diplomat, BBC News, National Geographic, and history books.

This historical method involves a procedure supplementary to observation, a process by which the historian seeks to test the truthfulness of the reports of observations made by others. Thus, I understand that the historical method attempts to narrate an accurate account of some aspects of life events and their scientific analysis and presentation [6]. The study aims for historical research to reveal and uncover the unknown, answer questions that have yet to be answered, and finally search and identify the relationship between past happenings and their links with the present. The process involves investigating, recording, analyzing, and interpreting past events to discover overviews that support understanding the past, the present, and to a limited extent, anticipating the future.

The choice of this methodology is hinged to conclude that making resourceful use of existing data is a quick and productive way for a new investigation with limited time and resources. Previous studies on the relationship between Pakis$\tan$ ISI and LeT inadequately explain the group's far-reaching influence to include recruitment in the Region or underestimate its global impact and danger to humanity and the peace-loving world. The analysis concludes that Islamabad needs to do more with its neighbors Afghanistan and primarily India, which are currently bearing the brunt of LeT terrorist activities, to stem the tide of violence.

The historical analysis provides a lucid portrait of the many characteristics of insurgency groups such as Lashkar-e-Tayyiba operated in the past. Thus, we ful- 
ly comprehend and appreciate how it is currently functioning [7]. On this account, we will better understand the group's mindset and possibly reveal where they are headed or what they are planning. Furthermore, historical analysis helps us understand and observe how Pakistan military, ISI, and LeT militant group behaved in the past and project their future behavior. For instance, war and intelligent historians have assessed war, even during peacetime, by retrospectively reexamining conflicts [8].

Besides, given most historical analysis examines severe occurrences, criminal behavior, and lived-experience throughout the life span, it provides us with a different prism to look into how militant groups view their world and understand their reasoning when making a decision. Although this approach is formulated against the framework and the environment we live in, we critically consider the threats and challenges we face currently. This method offers a workable map as a practical tool counter to the militant threat and adaptive ability to move with quickness to strike.

\subsection{The Importance of Jammu and Kashmir Territories}

Jammu and Kashmir, or simply Kashmir, is a region administered by India and considered one of the most volatile areas in the world. This small region has been subject to an intense contest between Pakistan and India for the last century. The two nations have fought three significant bloody wars in 1948, 1965, 1999, and several minor wars. Yet, despite these deadly conflicts, the two countries have still disagreed on the Disputed Territory. The Region has gained significant international attention since the disputes between India and Pakistan, which sometimes involve nuclear weapons, present significant global security threats. Besides, the fights over Kashmir have attracted considerable attention worldwide as people are interested in knowing the importance and the role of the area and its people to be contested by the two great regional powers. Significant literature works such as Vance-Cheng and Washington (2011) have identified economic, geographic, and religious factors as the significant root causes of the Region's conflicts.

According to Snow (2016), Kashmir holds great significance to these countries as it provides glaciers and freshwater. On the one hand, Kashmir provides water and generates massive electricity serving billions of people in India. On the other hand, India's population has increased faster over the past decades, signaling a growing need for electricity. The Indian government has identified Kashmir as the perfect solution to host the country's new hydro facilities [9]. This is because the Kashmir Rivers and water bodies possess the capabilities to generate hydroelectricity at significant magnitudes. According to Asoori (2020), the Region currently produces $3000 \mathrm{MW}$, but it can produce up to $16,000 \mathrm{MW}$ of power. This ability has attracted the Indian government's interest in the area [10].

On the other hand, Pakistan relies on these waters to support its agricultural activities. For instance, the Indus River is vital to Pakistan's agricultural progress, 
especially with limited rainfall in the lower Indus valley region. India's growing population continues to threaten Pakistan as the latter thinks its neighbor might divert water necessary for irrigation and use the resource as a weapon against the Pakistanis. Asoori (2020) explains that the country that controls Kashmir can easily cut off the other's water supply. Pakistan has always concentrated on the Region majorly because of the importance of water [11]. This is evident through the 2003 speech by the Chief of Jamat-ud-Dawa, Hafiz Saeed. He indicated that all the deposits of water are in Kashmir territory controlled by India. Therefore, the only way to guarantee Pakistan's economic prosperity is by increasing the country's efforts in fighting India over the area. Surprisingly, India has only $16 \%$ of the water carried by the Indus River [12]. However, Pakistan still fears that its neighbor can cut water supply because it controls the Kashmir region through which the river flows. Therefore, Kashmir emerges as a significant economic and security concern for both countries.

Kashmir territory is a region known for a variety of natural resources. For instance, the area is home to uranium, natural gas, oil, and gold. Besides, it also holds massive significance from a geopolitical point of view. For instance, the Region has served as a vital bridge connecting southern and central parts of Asia. The territory is the only direct route from India, Central Asia, and Europe. According to Asoori (2020), for Pakistan, the territory is critical for the China-Pakistan Economic Corridor (CPEC), which involves developing infrastructure and transportation networks linking the two nations involved. Additionally, several energy projects between Pakistan and China run through Pakistan-controlled Kashmir territory. Therefore, this territory is vital to Pakistan in its quest to connect with nations from Central Asia.

\subsection{India's Interference in the Internal Affairs of Pakistan and Pakistan's Resistance}

Since independence, the unresolved issues between the two countries caused further problems and interference in each other's internal affairs. For instance, unresolved territories issues, division of government assets, and devastating memories from the mass migration ensured that the two countries are still connected. Murnock \& Johnson (2006) indicated that negotiations between the two nations will always be complex, valid from both countries' perspectives. The most famous incident that portrayed India's interference in Pakistan's internal affairs came in 1971 when the former decided to intervene militarily in the civil war within Pakistan. According to a report by Park (2016), India's decision to intervene in the Bangladesh Liberation War was not precipitated by humanitarian reasons but due to intentions related to national interests [13]. India intervened in the 1971 war due to the militarization of refugee camps, shared Bengali identity, the need to tip a balance of power against Pakistan, and lack of international involvement. However, Murshid (2011) indicated that these reasons are not necessarily sufficient for military intervention accordingly [14]. 
The large numbers of refugees streaming into Indian territory were used as an excuse by New Delhi to intervene in the 1971 war (Zakaria, 2019) militarily [15]. Pakistan's loss would mean a potential surrender of East Pakistan and eventual independence. Independence to East Pakistan would mean Pakistan losing over half of its population, affecting its labor exploitations and access to natural resources. In other words, Pakistan would lose access to the Bay of Bengal and a maritime trade route to Southeast Asia. India would be left with a weaker rival in Pakistan's defeat. Therefore, India had several geopolitical interests in assisting the Bengalis in defeating the Pakistanis.

According to Park (2016), Pakistan had been an ally of the U.S. and other powers from the Arab world for decades. The country has received significant diplomatic and military assistance from these allies since 1954. During the same period, India remained a non-aligned nation with no powerful alliances. However, India developed a partnership with the Soviets to counter U.S. influence and successfully interfere in Pakistan's affairs. The two parties joined forces to dismember and weaken Pakistan for India's geopolitical interests.

\subsection{Pakistan Desire to Become a Power Broker in the Region}

Over the years, Pakistan has demonstrated its strong desire to be a power broker in the Southeast and Central Asia regions. In this case, power broking relates to influencing people and neighboring administrations to support, make specific decisions, strike deals, and implement policies that hold significant benefits to Pakistan. Most of Pakistan's power broking roles have been demonstrated towards nations like Afghanistan. Pakistan had been involved in cross-border support to the Taliban insurgency to continue its policy of destabilizing Afghanistan. Further proof has been reflected through the Pakistan army's policy of military crackdown against Pakistani Taliban in the tribal areas while refusing to act against Afghan Taliban operating within the same regions [16]. Besides, Pakistan has supported Jihadi groups in Afghanistan and India, both financially and militarily. This support aims to achieve specific foreign policy objectives and is closely associated with the military role in domestic politics and Pakistan's state-building projects.

Furthermore, the Pakistan administration and the military have relied on political partnerships with domestic Islamist parties to weaken secular political parties and civilian governments. These Pakistani Islamist parties possess special bonds with the Afghan Taliban and Kashmir Jihadi groups in India. These individual parties work together in attempts to weaken these neighboring nations. For instance, the Mujahideen in Kashmir have waged an armed struggle against the Indian government since the late 1980s. These efforts aim to free Kashmir from India and significantly reduce India's domination within the Region.

Pakistan's connection with the Taliban started much earlier in the 1980s. Then, Pakistani ISI and the U.S. supported each other to help invigorate the Taliban to fight the Soviet army invading the Region [17]. This strategy helped Pa- 
kistan resist the Soviet Union's pressure, avoid a pro-New Delhi administration at Kabul, and significantly impact the Afghan Pashtun contingent. The Pakistan government has also embarked on national policies parallel to U.S. national security interests for the country's benefit. As a result, the country has formed a solid partnership with the U.S. to combat terrorism and violent extremism, advance regional stability, integration, and inclusivity [18]. Accomplishing these objectives would enable Pakistan to improve its business environment and increase opportunities for American businesses, which will help the country solve its economic difficulties.

\subsection{The Normalization of Indian-Pakistan Relationship}

Over the histories of the two countries, efforts have been made towards normalizing their relationships, but the two nations have kept backsliding rather than showing progress. Historically, India and Pakistan have been staring warily across their shared fortified border while playing spy vs. spy games throughout the area [19]. The countries have continued to build their military weapons and amassed other nuclear weapons in preparation for any potential war, increasing tensions between them. Political issues have remained significant obstacles to progress in the Region regarding bilateral trade, investment, and free movement of people and commodities.

However, times have changed, and today, the two nations have crucial issues that they must focus on instead of warring. For instance, there is a growing need for economic growth and development in both countries to serve their fast-growing populations and poverty levels efficiently. Over the recent years, Indo-Pakistani relations have portrayed little progress towards normalcy, but significant obstacles have come in the form of leadership changes. The countries have witnessed the reigns of different leaders who possess different perspectives regarding the matter. For instance, in 2013, Indian Prime Minister Manmohan Singh expressed his sincere desire to end the prolonged hostility between the nations. According to Markey (2013), in 2007, secret back-channel talks between Singh and Pakistan president Musharraf almost delivered a successful compromise regarding the Kashmir conflict. However, Musharraf's political demise and 2008 terrorist attacks in Mumbai stalled the negotiations and halted any progress to improve the relations. As of now, there are growing fears that the potential successors of Singh and Musharraf will not be peacemakers like their predecessors, which will be a significant setback to normalizing the relationship between the two nations.

The recent release of Hafiz Saeed, the head of Lashkar-e-Taiba by Pakistan, has increased tensions between the two countries. India claimed that the decision revealed Pakistan's true face and indicated the latter's support for terrorist groups [20]. This decision only strains the relationship and endangers Pakistan's reputation in the efforts to curb terrorism. Pakistan must crackdown on all militants and other related entities to take its counterterrorism efforts seriously and 
normalize with India. In 2019, India's warplanes pounded a terrorist camp in Pakistan, adversely impacting the relationship [21]. India further restated that Pakistan must create an environment free of terror and hostility for the two countries to have normal neighborly relations.

\section{Analysis}

\subsection{Pakistan's Logic of Countering India's Influence in the Region}

India and Pakistan are both keens on influencing various activities and developments in the region, especially Afghanistan. Both nations intend to make significant progress in advancing their individual geopolitical, defense, and economic interests [22]. But more importantly, each side aims at preventing the other from gaining any advantage over the other. Thus, both countries have been concentrating and investing massively in countering each other's influence in the region for various reasons. For instance, Pakistan tends to counter India's influence in the area, especially in Afghanistan, due to fear that India will utilize Afghanistan to weaken its territorial integrity [23]. According to Islamabad, New Delhi aims at accomplishing this objective by stoking intense unrest among its ethnic Pashtun and Baloch populations.

Furthermore, Pakistan has strived to block India's influence in the Region because the former is aware of the latter's demographic, economic, and military advantages. Therefore, any additional events that may benefit India are considered a loss to Pakistan. Frederic Grare, a former French diplomat experienced in South Asian issues, stated that Pakistan perceives all Indian activities in Afghanistan as a ploy against Islamabad, whether it is an economic investment, infrastructural, or any other related activity [24]. India's efforts are considered deliberate strategies of encirclement aimed at trapping and destroying Pakistan. For this reason, Islamabad will ensure that New Delhi's interests in Afghanistan are blocked whenever and wherever possible to minimize the threat.

Pakistan's logic of countering India's influence in Afghanistan also relates to Islamabad's intention to establish a safe environment for Pakistani-trained extremists. Hanauer and Chalk (2012) believed that this logic would enable Islamabad to create a rear base for training Islamist militants such as LeT, JeM, and HuM for non-attributable attacks in Kashmir, Jammu, and other Indian territories. In addition, Pakistan and India are constantly competing in building economic links with the other Central Asian Republics (CARs). Therefore, countering India's influence, especially in Afghanistan, would enable Islamabad to have a firm grip on the northern trade routes. Furthermore, this strategy would allow Pakistan to undermine Iran's and India's efforts of expanding their economic ties with CARs.

\subsection{The Influence and Cozy Relationship between Pakistan's ISI and LeT}

LeT is a militant Islamist organization founded in the Kunar Province of Afgha- 
nistan, 1987 but is currently based in Pakistan and Kashmir [25] [26]. The group was formed when Pakistan provided a steady supply of volunteers and massive funding to armed groups like LeT. As a result, the group has been strongly associated with Pakistan's military and Inter-Services Intelligence Agency, Al-Qaeda, and Jaish-e-Muhammed. The connection between this group with ISI has been a significant surprise, which has triggered several research projects to investigate the nature of this relationship and the mutual influences and benefits to both parties.

Pakistani military and ISI have had a significant influence on LeT's formation and survival over the years. For instance, the ISI and other government bodies and officials play an essential role in stabilizing the group by supplying funds to build and renovate the Muridke campus, the group's headquarters, and other training camps [27]. Additionally, ISI is helping LeT develop into the largest militant network in Pakistan by maintaining thousands of offices countrywide. The Pakistani military and ISI have even allowed LeT to claim two dozen camps for launching fighters across the Line of Control. Besides, the Pakistani army and ISI have been integral in supplying arms, additional members, and offering professional directions about different operations. For example, Pakistan ISI trained and directed LeT members to participate in the fight against the Soviets and play the same role towards India and Afghanistan.

On the other hand, the group has benefited the Pakistan military and ISI in the continuing struggles against India over Kashmir. LeT has been providing soldiers to go to war alongside the Pakistani army and ISI. For example, LeT jointly helped the military forces of Islamabad to conduct the Kargil Heights attack against India. This group also assists the Pakistan military forces in executing various attacks against the country's enemies. For example, LeT conducted the Mumbai attacks on behalf of the Pakistani government. Pakistani Army, ISI, and LeT all planned, launched, and coordinated the attack from Pakistani territories in Islamabad. The cozy relationship between these two parties has also been reflected in the limited terror activities on Pakistani soil. LeT does not necessarily target Pakistan's establishments in its attacks, strengthening the belief that the Islamist group is a close ally to the ISI.

The influence and mutual connections between the Pakistan government, $\mathrm{Pa}$ kistan ISI, and LeT have also been evident whenever a leader of the Islamist group has been arrested. In most cases, leaders of LeT and other government-backed militant groups are arrested; they are guaranteed no impending danger and conviction. For instance, LeT's leader, Saeed, has been arrested on multiple occasions over the years, but he has never been seriously hampered. Whenever an attack is linked to LeT, Saeed is likely to be detained in the form of a house arrest, and his movements impeded during the arrest. However, within a short period, the Pakistani court will likely declare Saeed's detention illegal and therefore refuse to charge or drop all the charges against him under the claim of the absence of evidence leading to his release. This pattern has existed for years and 
continues to apply as the Pakistani government offers cover for Saeed.

Pakistan ISI and the government officials also tend to publicly defend and protect the Islamist groups on various occasions against international communities to demonstrate the two parties' mutual coexistence. According to Operational Environment Assessment (OEA) and Tradoc Intelligence Support Activity (TRISA) (2012) threat reported that in 2012, Saeed publicly called for Jihad against the United States. When the international community questioned his comments, two separate officials of the Pakistani government defended his remarks by claiming that he was only participating in 'deradicalization and rehabilitation of former jihadis'. The international community intends to disband this militant organization, but the Pakistani government has consistently shown a lack of cooperation. For instance, following the 2008 Mumbai attacks, the United Nations banned LeT, the U.S., in 2012 added Hafiz Saeed to the Rewards for Justice program [28]. The Pakistani government and ISI indicated their support to U.N. and U.S. efforts by imposing travel restrictions on Saeed. In reality, these government bodies had allowed Saeed to walk around in Pakistan and oversee LeT's activities.

Lashkar-e-Taiba's current activities are profoundly entrenched with the strategic aims of the Pakistani military establishment. This is why LeT has morphed as the leading proxy in Pakistan's fight against India in general and primarily in the Disputed Territories of Jammu and Kashmir. Also, LeT, as a militant group, has the most well-established infrastructure at Muridke. Thus, it makes sense from Pakistan's standpoint why it continues to protect and sponsor LeT. And Pakistan security establishments maintain considerable control over LeT militancy activities within its borders, India and Afghanistan.

\subsection{Pakistan's Reasons for Sponsoring Militant Groups against India}

Several geopolitical reasons explain why Pakistan would be tolerating militant groups such as LeT and the Afghan Taliban. However, little evidence exists to justify why Islamabad would support and sponsor groups that do so much damage to the country's international reputation, jeopardize the citizens' safety and threaten its national interests [29]. Instead, it is clear that Pakistan exceedingly sponsors these groups to fight India's influence in the region. Islamabad seems to support these groups against India because of the ever-growing fear that the Indian government can form strong alliances with neighboring countries such as Afghanistan [30]. These partnering countries could help each other in encircling Pakistan.

Pakistan fears that an India-Afghan collaboration would help establish Kabul as a haven for anti-Pakistan militant groups. If this happens, Afghanistan will become a dangerous playground for outside powers such as Pakistan, limiting its benefits and power broking duties. Therefore, Pakistan supports the Afghan Taliban in maintaining significant control in Kabul or obtaining formal political power. Felbab-Brown (2018) suggested that Islamabad also supports the Taliban 
because Pakistan establishments believe it is the only political ally among all the political authorities in Afghanistan. Moreover, Pakistan is afraid that directly targeting Indian and Afghanistan-oriented militant groups will be dangerous as it would be provoking major retaliation in Pakistan's Punjab heartland.

Pakistan also sponsors LeT and other militant groups against India to demonstrate power and military backup in any war. This is shown by the partial admission by the government and ISI officials of association with the militant groups. Also, according to Felbab-Brown, (2018), complete refusal of supporting LeT is likely to portray Islamabad as a weak nation with little military intelligence to various parties such as India, opposition politicians, and other anti-Pakistan militant groups. Apart from weakening Pakistan's hand in international bargaining, disassociation with the militant groups would reduce its bargaining powers towards India. In general, Shapiro and Fair (2010) indicated that Pakistan's reasons for supporting and sponsoring militancy relate to poverty, low education levels, religious factors such as support for sharia laws, and other political objectives. Besides, Pakistan supports LeT and other militant groups to earn public support [31]. Moreover, some citizens approve of government association with these militant groups since they believe such organizations accord them significance.

\subsection{Helping Pakistan Regain Control and Re-Establishing Its Security and Stability}

Pakistan needs to combat militant groups and violent extremism in the region to establish a bright future characterized by safety and stability. The instabilities and insecurities within this nation impact other countries such as China, India, Iran, Saudi Arabia, Afghanistan, and even the United States [32]. The rising levels of violence and terror activities have proven to be a significant challenge to the country's police since they are corrupt, incompetent, and ill-equipped. Respectively, the government needs military and financial assistance and implement effective policies to regain control of its territory from the hands of an enemy within the nation. First, Islamabad must follow through with the promised war against violent extremism by being on the same page with various powers such as the U.S. In the past, Pakistan's civil and military leaders have indicated their support for the war on terror, but their actions have shown conflicting stories. Failure to comply and partner with other powers in the fight against violent extremism is likely to invite pressure and interference from other countries such as India.

At this point, Pakistan having external conflicts with powerful countries such as India is not advisable as it is dangerous in the quest to regain safety and stability. While India has a powerful military intelligence and is heavily armed with nuclear weapons, Afghanistan is an emerging force with a fast-growing army. Warring with these nations would adversely impact Pakistan and jeopardize its efforts to restore security. Besides, the country must also improve its efforts in asserting control over its jurisdiction. So far, Pakistan has failed in controlling 
Islamabad, which has facilitated the growth of several militant groups. Nawaz (2016) believes that these groups receive primary financial backings from individuals and organizations within the country and other external actors. With the growing influence of militant organizations, there is an increase in the risk of sectarian, ethnic, and rural-urban fights that could overpower the country's military.

Previous analysis in this article has revealed that the significant Pakistani enemy lives within the country. Therefore, the government must change its landscape and establish a new one characterized by an environment that discourages nurturing militant organizations. For instance, Madrassa networks associated with militant organizations have been identified as a significant obstacle to the country's counterterrorism efforts [33]. These madrassas tend to spread extremism, accept funds from abroad, and provide active participants in sectarian conflicts. Thus, the country can accomplish this objective by eliminating the current influence of the Islamic extremists on the country's education and political systems. Besides, Pakistan must also focus on building a stable and viable economy to help in boosting security, regaining control, and re-establishing stability. A vibrant and robust economy will assist in reshaping the people's perspectives about national priorities and earn their support towards accomplishing bigger goals than a century of wars.

Additionally, LeT has several charitable activities that seem to blind the people and gain its support from the public. However, the government should create more job opportunities to meet their ambitions and aspirations, especially for youths. This strategy will increase the youth's purchasing power, which will be crucial in shifting their reliance on LeT, and instead support the government's ambitious goals. In so doing, Islamabad will earn the people's support, ease their pain, boost their morale, and work closely with Islamabad. And in turn, it will marginalize and weaken the influence of militant and terrorist groups, and more so, the influence of LeT on youth and other citizens.

\subsection{U.S. Unyielding Approach}

The U.S. approaches to help Pakistan restore security, regain stability, and resume harmonious relations with its neighbors have not yielded many outcomes. The U.S. has been pressurizing Pakistani administrations to change their educational and political systems by reducing LeT's influence. However, implementing new education and political systems is likely to take time. Therefore, the U.S. emphasizes that Pakistani administrations maintain a high degree of patience for the technique to work effectively. Most countries' significant attention has focused on establishing the most influence on Afghanistan. The U.S. has also been focusing on stabilizing Afghanistan by making the people see, understand, and believe that the country is making significant progress towards reconstruction. This technique also involves advising the Pakistan administration to work closely with the Afghanistan government to earn people's support. 
The country has also been advised to establish a robust public communication plan to ensure that a leader's vision is well known to everyone. This approach has been tipped to help in avoiding the death of an idea when a leader dies. The U.S. has also pushed Pakistan to appoint a professional and experienced national internal security advisor to help in ensuring internal security policies are implemented appropriately. According to Rumi (2015), he suggested that the post holder should also monitor the coordination across government on behalf of the prime minister. Another recommendation relates to enhancing the capacity of the country's institutional structures, especially the judiciary. Over the years, $\mathrm{Pa}$ kistan's judicial system has been deemed inefficient due to its slow nature in cases' disposal, excess bureaucratic protocols, shortage of judicial officials, lack of professional training, and corruption [34]. All these setbacks can be addressed through organizational reforms and technical and financial support.

The U.S. has also strengthened Pakistan's police system by providing professional training and supplying military equipment. However, this counterterrorism assistance technique has failed in helping in the successful conduction of investigations, convictions of suspected criminals and stabilize vital areas of the country [35]. Additionally, the U.S.'s new counterterrorism approaches in Pakistan have focused on helping the country enhance its efforts of keeping nuclear arsenal safe and secure. However, this technique has not successfully prevented the illegal transfer of nuclear weapons and protected them from unauthorized access [36]. Finally, for decades, the U.S. has assisted Pakistan in helping victims of wars and conflicts to earn the people's support and marginalize militant groups.

\subsection{Proposing Recommendations and Finding Common Ground for New Rapprochement}

First, the country should build on the recently implemented regional and international diplomatic initiatives. Pakistan, India, the U.S, Iran, and even Afghanistan should embark on several high-level meetings and consultations involving leaders from both nations. During these meetings, the parties must address the long-standing hostility between Pakistan and India. The U.S. and its international allies should intervene in conducting regional diplomacy to restart the dialogue protocols between India and Pakistan [37]. Many people still wonder if the U.S. can still promote peace in the subcontinent. The perspective of this article is a resounding yes, because according to Yelena Biberman (2021), an associate professor of political science at Skidmore College while writing for the Atlantic Council, strongly argues by promoting eight reasons why the United States should promote Kashmir peace talks now.

Realistically, the United States can do many things; she believes that the U.S. Secretary of State, Blinken, can promote many things because the time is suitable for Kashmir peace talks. He can indeed play a constructive role in bringing India to the table. But, for example, when promoting Jammu and Kashmir peace talk, the U.S. must be crystal clear that "it means what it says and says what it means" 
about human rights, self-autonomy, and democracy. The stakes are too high, and it will be a faux pas for the United States not to be involved in helping both sides to bilateral negotiation.

Professor Biberman also reminds us that the current situation in Kashmir is drawing China into the conflict. In the past, China has been neutral about Kashmir's dispute. However, Beijing has begun openly speaking against it. We all know that India and China are rivals, and it could build up tension to the existing hostility in the region [38]. The conflict between China and India is semidormant, fresh in our mind, but the Sino-Indian border crisis constantly reminds us. It is not a secret that the U.S. views India as a vital strategic ally in the Indo-Pacific to minimize and counter-balance the influence of China in the region.

For this reason, it is the stance of this article that the United States should not play an official mediator's role. Instead, Secretary Blinken should vibrantly encourage his Indian and Pakistan counterparts to contemplate Kashmir peace dialogue as a worthwhile strategy for bringing stability in the region. As stated earlier, the U.S. can do many things, such as talking to each side separately and arranging for a possible bilateral negotiation, equally advising both sides on the benefits, and preventing any internal or external forces from spoiling the negotiation.

The U.S. needs to start focusing on establishing relations with a much broader range of players and interests. Over the years, it has been proven that the U.S. cannot rely on partnering with top leaders and military chiefs only to further its interests in Pakistan. For this reason, new approaches should focus on forming alliances with different institutions without selecting favorites or endorsing specific leaders or political parties over the others. The process must also involve civilian institutions and agencies to support the current democratic transition of power.

Furthermore, the U.S. should also consider formulating an expansive plan to establish wide contacts and partnerships between institutions in the United States and Pakistan. This proposal involves partnerships between lawyers' groups, think tanks, civil society organizations, and the general public. Besides, facilitating cultural and educational exchanges is crucial in building more robust ties between the two countries. Another recommendation relates to formulating and signing a bilateral strategic framework agreement with Pakistan. The frequent trilateral meetings between Pakistan, the U.S., and Afghanistan have proven practical sessions for discussing security and diplomacy issues among the countries. Therefore, there is a growing need for a similar framework agreement between the U.S. and Pakistan to facilitate a far more profound, better coordination and understanding of multiple concerns between the two parties involved. The U.S. must work closely with Pakistani leaders to set common objectives regarding military cooperation, security matters, political, economic, and diplomatic concerns.

A broad consensus exists within the U.S. foreign policy regarding shifting 
more significant attention to Pakistan. However, more mobilization needs to be done, especially among members of Congress and the general American public, concerning the reasons for the administration's actions towards Pakistan, Afghanistan, and India. The transparency and accountability of the process are likely to win the public's support for a possible long-term relationship with Pakistan. Future efforts should focus more on youths as journalists and academics have already reported excessive force towards this population. Soldiers' indiscriminate use of force towards youths and other civilians as part of counter-insurgency techniques is particularly worsening. These actions, along with enforced disappearances, extrajudicial murders, torture, and other rights abuses, seem to fuels the militancy than contain it. Therefore, the Pakistani administration should reform the Public Safety Act to incorporate international human rights and remove all sorts of abuses that might lead to resistance and retaliation. Lastly, the U.S. should immediately cease all military and economic aid to Pakistan and instead make the remaining aid contingent upon compliance behaviors and cooperation.

Also, the Islamabad government must outnumber LeT charitable undertakings to provide various needed social services to the most vulnerable members of its society. And its utmost objective must be to meet the ambitions and aspirations of its younger generation. Additionally, Islamabad must improve and strengthen its governance capacity and expand social service delivery. The gist is that Pakistan must create millions of well-paying jobs that bring economic hope and empower the youth in particular and others with purchasing power. And doing so will bring equanimity and at the same time help its citizens in shifting their reliance on LeT and favorable perception of LeT to working with Pakistan's government.

\subsection{Significance of the Study}

The study highlights the significant impact of the Jammu and Kashmir dispute vis-a-vis the Pakistan-India relationship. It contextualizes the complexity of the mediation process by both nations, which demands critical cognizance of the peculiar changing aspects of the competing internal interests of both sides. This research assessed the significance of India and Pakistan's geopolitical and cultural history and described the underline complexity that generated and fueled the Jammu and Kashmir conflict. Additionally, this research postulated that the dispute over Kashmir territory indeed influenced the course of action taken by India and Pakistan regarding Afghanistan. In turn, if the dispute is not resolved amicably, it could weaken Pakistan standing, and possibly U.S. standing in the region and its efforts in stabilizing Afghanistan.

Additionally, this research adds to the literature body on conflict, peace, and counter-terrorism fields by contributing a fresh approach to analyzing and looking at the issue of security in the Indo-Pakistan region. By laser focusing on flashpoint discourses, this inquiry ripostes how the establishments personify 
disputes on both sides and how these have consequences on resolving the enduring crises as well as for policymaking.

Furthermore, many previous studies regarding the Indo-Pakistan dispute have been viewed from a historical approach by focusing on a conceptual lens. As a result, they have contributed to some extent to the significant aspect of the existing conflict. Nonetheless, they do not go far enough in providing a working framework. Thus, there is an absence of tangible outlooks and underpinnings to understand the deep-rooted conflict better, outline and give practical recommendations to help lessen the intensity of the dispute. Consequently, the corresponding lack of existing pragmatic strategic inquiries offers validation for this research.

\subsection{Study Contributions and Limitations}

The current study has added crucial insight to the existing knowledge regarding the cozy relationship between Pakistan, ISI, and militant groups. Before providing a deep analysis about this topic, the study investigated the long-standing rivalry between India and Pakistan. It highlighted the most significant incidences of conflicts between the two countries. Furthermore, the study provided background reasons for the rivalry between India and Pakistan, including disputes over Kashmir territory, which is rich in natural resources targeted by both countries. Consequently, Pakistan has embarked on sponsoring militant groups to help fight off India's influence and increase its own within the Region. The study has discussed how this cozy relationship has adversely affected Pakistan's reputation to the international community and the U.S., leading to several questions about Islamabad's commitment to fighting terror. The study has also provided several recommendations that can be implemented to help Pakistan fight militancy, restore safety, and regain stability. However, despite giving new insights to this field of study, the study did not discuss the root causes of the Indo-Pakistani rivalry from a religious perspective.

Additionally, while LeT's influence has expanded to other countries within the region, the study primarily centered on its impact on India, Pakistan, and Afghanistan. Lastly, as alluded to that this research was limited in understanding the history of the ongoing hostility between Pakistan and India and the cozy relationship between Pakistan ISI and militant and terrorist groups, primarily LeT operating within its frontiers. Hence, it will be fascinating to further the research in this area by answering the following question: what will it take for Pakistan to stop supporting militant extremist groups and become a U.S. true strategic and economic partner in the Region?

\section{Conclusions}

The study centered on understanding the cozy relationship between Pakistan ISI and Lashkar-e-Taiba. The two parties indeed have a mutually benefiting connection with LeT assists ISI in conducting its war against India. At the same time, 
ISI supplies the necessary weapons and provides funds to the militant group. However, while Pakistan continues to sponsor LeT, the relationship has adversely impacted the country through reduced control over the state, increased security tensions, deteriorating economy, and poor relationships with the international community and neighboring countries.

Indeed, Pakistan's security stability and economic prosperity hinge on how Islamabad's determination to control the terrorist and militant groups within its borders. If instability remains in place, all other development projects attempts are destined to fail, and the situation on the ground will continue to worsen. The Indo-Pakistan conflict is still unresolved, and Jammu and Kashmir territory remain unstable today. Given the protracted history of conflict between both sides, changing the course of action will not be easy. However, doing nothing productive is not an option because the stakes are too high to overlook. The existing calculated strategy for Pakistan to achieve its goal is ineffective and counterproductive. Thus, attaining some measure of lasting and sustainable peace and stability for the Indo-Pakistan debacle demands the willingness of each side to negotiate in good faith of a political agreement pleasing to both sides.

Pakistan needs meaningful reforms on combatting corruption, economic inequality, nepotism, improve fiscal transparency, military control of all assets that have caused economic and security instability. Also, Pakistan's economy and the fiscal deficit had reached a breaking point. Simply put, weak economic growth and a lack of jobs and opportunities generate and translate to conditions that are ripe for security instability. Lastly, through the help of the U.S., Pakistan can restore stability and security by establishing relations with a broader range of players and interests, including civilian and public institutions. However, the country can only be prosperous in its counterterrorism goals when it becomes more focused, transparent, accountable, and better in the organization of its current distinct efforts.

\section{Conflicts of Interest}

The author declares no conflicts of interest.

\section{References}

[1] Bates, C. (2011) The Hidden Story of Partition and Its Legacies. http://www.bbc.co.uk/history/british/modern/partition1947_01.shtml

[2] Pillalamarri, A. (2019) The Origins of Hindu-Muslim Conflict in South Asia. The Diplomat, Washington.

[3] Hasan, S. (2005) India and Pakistan: Common Identity and Conflict. Refugee Survey Quarterly, 24, 74-80. https://doi.org/10.1093/rsq/hdi085

[4] Sunil, D. (2012) History as the Architect of the Present: What Made Kashmir the Nucleus of South Asia Terrorism India-Pakistan Conflict and Its Impact on U.S. Homeland Security. Master's Thesis, Naval Postgraduate School, Monterey. https://calhoun.nps.edu/handle/10945/6788

[5] Rhea Vance-Cheng, B.A. (2011) Discourses of War and Peace in Kashmir: A Posi- 
tioning Analysis. Master's Thesis, Georgetown University, Washington DC. https://repository.library.georgetown.edu/bitstream/handle/10822/553270/vance-ch engRhea.pdf? sequence $=1$ \&isAllowed $=y$

[6] Raghavan, P. (2013) The Finality of Partition: Bilateral Relations between India and Pakistan, 1947-1957. Doctoral Dissertation, University of Cambridge, Cambridge.

[7] Howell, M. and Prevenier, W. (2001) From Reliable Sources: An Introduction to Historical Methods. Cornell University Press, Ithaca.

[8] Olstein, D. (2014) Thinking History Globally. Palgrave Macmillan, London.

[9] Clark, C. (2012) The Sleepwalkers: How Europe Went to War in 1914. Allen Lane, London.

[10] Snow, S. (2016) Analysis: Why Kashmir Matters. The Diplomat, Washington.

[11] Asoori, P. (2020) A Look into the Conflict between India and Pakistan over Kashmir. E-International Relations.

http://www.sirjournal.org/research/2020/10/19/a-look-into-the-conflict-between-in dia-and-pakistan-over-kashmir

[12] Naseer, A.K. (2013) Geopolitical Significance of Kashmir: An Overview of Indo-Pak Relations. IOSR Journal of Humanities and Social Science, 9, 115-123.

[13] Murnock, T. and Johnson, T. (2006) Stability in Pakistan: Realizing the Vision of Enlightened Moderation. Master's Thesis, Naval Postgraduate School, Monterey. https://www.nps.edu/documents/105988371/107571254/Stability+in+Pakistan+Mur nock+thesis.pdf/076188d9-81a4-4723-bcd0-78cd6097c636

[14] Park, D.C. (2016) India's Intervention in East Pakistan: A Humanitarian Intervention or an Act of National Interest? Synergy: The Journal of Contemporary Asian Studies, 1 .

[15] Murshid, N. (2011) India's Role in Bangladesh's War of Independence: Humanitarianism or Self-Interest? Economic and Political Weekly, 46, 53-60. https://www.jstor.org/stable/41719989

[16] Zakaria, A. (2019) By Marking Genocide Day, Bangladesh Seeks to Remember What Pakistan Wants to Forget.

https://scroll.in/article/832420/by-marking-genocide-day-bangladesh-seeks-to-reme mber-what-pakistan-wants-to-forget

[17] Hakimi, A. (2012) Sources of Tension in Afghanistan and Pakistan: A Regional Perspective-The Changing Nature of Power and Sovereignty in Afghanistan.

https://www.cmi.no/publications/file/5920-the-changing-nature-of-power-and-sove reignty-in.pdf

[18] Siddique, Q. (2011) Pakistan's Future Policy towards Afghanistan: A Look at Strategic Depth, Militant Movements and the Role of India and the US. https://www.econstor.eu/bitstream/10419/59843/1/66870022X.pdf

[19] Integrated Country Strategy: Mission Pakistan (2019). https://www.state.gov/wp-content/uploads/2019/04/ICS-Pakistan_UNCLASS_508.p df

[20] Markey, D.S. (2013) Politics and Indo-Pakistani Normalization. Council on Foreign Relations.

https://www.cfr.org/expert-brief/politics-and-indo-pakistani-normalization.

[21] Markey, D. S. (2013). Politics and Indo-Pakistani Normalization. https://www.cfr.org/expert-brief/politics-and-indo-pakistani-normalization

[22] The Economic Times (2021) Peace, Stability, and Prosperity in South Asia Hinge on Normalization of Relations between India, Pakistan: U.N. Official. The Economic 
Times.

https://economictimes.indiatimes.com/news/defence/peace-stability-and-prosperity -in-south-asia-hinges-on-normalisation-of-relations-between-india-pakistan-un-off icial/articleshow/83006905.cms

[23] Hanauer, L. and Chalk, P. (2012) India's and Pakistan's Strategies in Afghanistan: Implications for the United States and the Region. RAND, Santa Monica. https://www.rand.org/content/dam/rand/pubs/occasional_papers/2012/RAND_OP 387.pdf

[24] Constantino, Z. (2020) The India-Pakistan Rivalry in Afghanistan. United States Institute of Peace.

https://www.usip.org/sites/default/files/2020-01/sr_462-the_india_pakistan_rivalry_ in_afghanistan.pdf

[25] Oimstead, J. (2014) India-Pakistan Relations: A Destructive Equilibrium-The Diplomat.

https://thediplomat.com/2014/11/india-pakistan-relations-a-destructive-equilibriu $\underline{\mathrm{m} /}$

[26] Tellis, A.J. (2012) The Menace That Is Lashkar-e-Taiba. Carnegie Endowment for International Peace.

https://carnegieendowment.org/2012/03/13/menace-that-is-lashkar-e-taiba-pub-47 512

[27] Howenstein, N. (2008) The Jihadi Terrain in Pakistan: An Introduction to the Sunni Jihadi Groups in Pakistan and Kashmir. https://bradscholars.brad.ac.uk/bitstream/handle/10454/2224/resrep1.pdf?sequence $=1$

[28] OEA Team and TRISA (2012) Lashkar-e-Taiba: The Three-Headed Snake. https://community.apan.org/cfs-file/__key/docpreview-s/00-00-02-42-23/Lashkar_2 D00_e_2D00_Taiba.pdf

[29] Singh, K. (2017) Lashkar-e-Taiba: Evolving into a Hybrid Entity? Centre for Land Warfare Studies (CLAWS).

https://www.claws.in/publication/lashkar-e-taiba-evolving-into-a-hybrid-entity/

[30] Shapiro, J.N. and Fair, C.C. (2010) Why Pakistanis Support Islamist Militancy. International Security, 34, 79-118. https://doi.org/10.1162/isec.2010.34.3.79

[31] Felbab-Brown, V. (2018) Why Pakistan Supports Terrorist Groups and Why the U.S. Finds It So Hard to Induce Change. Brookings. https://www.brookings.edu/blog/order-from-chaos/2018/01/05/why-pakistan-supp orts-terrorist-groups-and-why-the-us-finds-it-so-hard-to-induce-change/

[32] Tankel, S. (2011) Lashkar-e-Taiba: Past Operations and Future Prospects. New America Foundation, Washington, DC.

[33] Nawaz, S. (2016) Countering Militancy and Terrorism in Pakistan. United States Institute of Peace.

https://www.usip.org/sites/default/files/SR393-Countering-Militancy-and-Terroris m-in-Pakistan-The-Civil-Military-Nexus.pdf

[34] Rumi, R. (2015) Charting Pakistan's Internal Security Policy. The United States Institute of Peace.

https://www.usip.org/sites/default/files/SR368-Charting-Pakistans-Internal-Security -Policy.pdf

[35] Ahmad, M., Banerjee, D., Bhatnagar, A., Fair, C., Felbab-Brown, V., Haqqani, H., Karim, M., Karim, T., Katju, V., Raja, C., Nelson, M. and Ranade, J. (2016) Mapping Pakistan's Internal Dynamics: Implications for State Stability and Regional Security. 
The National Bureau of Asian Research.

https://reliefweb.int/sites/reliefweb.int/files/resources/SR55_Mapping_Pakistan_Feb ruary2016.pdf

[36] Korb, L., Katulis, B. and Cookman, C. (2009) Meeting the Challenges in Pakistan: Trip Report and Recommendations for U.S. Policy. Center for American Progress. https://cdn.americanprogress.org/wp-content/uploads/issues/2009/05/pdf/pakistan _trip_report_exec_summ.pdf

[37] Roggio, B. (2016) Pakistan: Friend or Foe in the Fight against Terrorism? https://www.govinfo.gov/content/pkg/CHRG-114hhrg20742/html/CHRG-114hhrg2 0742.htm

[38] Biberman, Y. (2021) Eight Reasons Why the United States Should Promote Kashmir Peace Talks Now.

https://mwi.usma.edu/the-case-for-a-kashmir-peace-deal-now 